\title{
Smart Vest Prototype for Sitting Position Correction
}

\author{
Arif Supriyanto ${ }^{1,}$ Agustian Noor ${ }^{2}$, Yunita Prastyaningsih ${ }^{3}$
}

\author{
${ }^{1}$ Arif Supriyanto 1 \\ ${ }^{2}$ Agustian Noor 2 \\ ${ }^{3}$ Yunita Prastyaningsih 3
}

*Corresponding author.Email: arif@politala.ac.id, agustiannoor@politala.ac.id, yunitaprastya@politala.ac.id

\begin{abstract}
In this study, a vest was created that can provide early warning to user about the wrong sitting position to prevent the risk of health problem due to the wrong sitting position. This research was divided into two parts, namely the hardware part and the software part. In the hardware section there was a sensor that can detect the tilt angle of the sitting position and a buzzer that sounds if the user was sitting in the wrong position, while in the software section there was an android application on the smartphone that informs the tilt angle of the sitting position to the user. If the vest user was sitting at the wrong angle position then the vest activated the buzzer (sound) to alert the user so that the user could fix the sitting position correctly. Based on the test result of the ideal sitting position was when the body remained upright that was with the tilt angle $90-100$ degrees.
\end{abstract}

Keywords: sitting position, IoT, microcontroller.

\section{INTRODUCTION}

\subsection{Background}

Nowday computer usage has penetrated all societies layer because it can facilitate and make all kind of work fastly so that many people spend time for sitting in front of computer to finish their work.

The correct sitting position means keeping vital parts of a person's body in the right posture ang using the right muscle support as well. However, most people do not pay attention to correct sitting position when working, the bad sitting habit sustainably for a long time can conduce health problems for themselves. Sitting too long can lead to the risk of hemorrhoid, heart disease, diabetes, obesity, and injuring the joint, muscle body posture. One of the risks that are often occurred is back pain, it is often caused by muscle or joint injuries in the waist area, this occurs because of the wrong sitting position for a long time.

Several studies on position detection were carried out (Budiarto et al., 2016) This study aims to create a sitting position detection system using BETASPC. BetaSPC is a technology that uses a microcontroller (Arduino Duemillanove) as a processor and sensor (infrared) based on the amount of light reflected on a stretched garment (when the body is bent). Detected body positions consisted of sitting position, sleeping upturned, sleeping on the left side, and sleeping on the right side. The proposed technique uses a slope angle calculated based on the acceleration generated by the three $\mathrm{x}, \mathrm{y}, \mathrm{z}$ axes on the accelerometer sensor. Based on the results of testing the proposed technique is able to detect body position in activities using a smartphone by $82.5 \%$ of 40 times of testing (Liandana et al., 2017). In this study, an information system was created that can remind users of the length of time sitting in order to avoid the risk of health problems due to sitting too long. The device that is designed and made consists of two parts, namely the seat pad and the application on the smartphone. On the seat cushion, a limit switch sensor is placed to detect the sitting position and a temperature sensor to detect the temperature of the bearing as an indicator of the length of sitting (Madona et al., 2018) .

This research was conducted to design and build a prototype of a smart vest for correction of the sitting position that is able to provide early warning on the wrong sitting position. In this study divides into two parts, namely the hardware part dan the software part. The hardware part is used to determine the wrong sitting position, the system installed on the hardware must be accurate. Accurate data is based on the result of sensor reading of measured object. The sitting position data generated by the sensor will be transmitted to the microcontroller and processed in such a way then it is transmitted to the smartphone using Bluetooth transmissior media.

Whereas for the software part is used for monitoring the sitting position. The monitoring system is displayed using android application. The display on the smartphone informs the tilt angle of the sitting position which is gotten from the sensor attached to the vest. Monitoring can be done anywhere and anytime outside the object location.

\subsection{Identify Problems}

In order to build a smart vest for correction of this sitting position, it is necessary to calibrate or check and adjust the accuracy of each sensor used based on the 
datasheet and determine the minimum and maximum limits of the value of the results of each sensor reading.

\subsection{Limitations of Problems}

This research that has problem limitations can be done more focused so that optimal results are obtained. Similarly, with this study in order to obtain maximum results, it is necessary to be given the following problem limitations.

1. The part of the body that is used as a sensor measurement object only on the back and waist area.

2. The monitoring system on the vest displays information on the angle of inclination of the back area.

\subsection{Problem formulation}

Based on the background that has been outlined, the problem formulation for this study is how to design and build a smart vest for correction of sitting position?

\subsection{Research objectives}

Build a smart vest to provide early warning to the user when in the wrong sitting position.

\section{LIBRARY REVIEW}

Low Back Pain (LBP) is defined as pain, muscle tension or stiffness felt between the bottom rib angle and the lower buttock fold (Putra RS , Legiran, 2018) . According to Freitas (Freitas et al., 2011), the causes of low back pain is variate, such as biomechanical pressure, individual characteristic and occupational factors. Many factors that cause LBP in developing country is physical stress, it is including continuous lifting work, driving a vehicle and sitting too long.

Arduino nano is a microcontroller that uses the ATmega328P chip. Arduino nano processes at voltages of 5-7 volts (Kurniawan \& Rivai, 2018). Arduino nano can be programmed using Arduino IDE (Integrated Development Environment) which is connected using USB wire type B. Arduino nano has 6 pins of PWM (pulse With Modulation), 8 analog pins, 2 SDA pins and SCL that can communicate for $12 \mathrm{C}$. The Arduino Nano is a compact board similar to the UNO. The Arduino Nano is a small, complete, and breadboard-friendly board based on the Atmega328 (Arduino Nano 3.x) (Kurniawan A. , 2019).

IMU (Inertial Measurement Unit) is a sensor used to measure the speed, orientation and gravity. The next component that composes the IMU Sensor is the gyro sensor, the way this sensor works is to detect motion according to gravity, or in other words it detects the user's movement (Kurniawan \& Rivai, 2018). This sensor is used to measure an object fastness by integrally accelerating an object to the time. IMU sensor can be used to measure yaw, pitch and roll angle (Hidayatno, 2011).

\section{RESEARCH METHODS}

This section explains the design methods and device manufacture of used a smart vest prototype for the sitting position correction.

According to the fig. 1 can be describe that a smart vest works based on the angle of back tilt at the time of sitting detected by the vest. In order to detect the sitting position, so the vest is equipped with an IMU sensor placed on the back of the vest. The IMU sensor is a sensor consisting of an accelerometer sensor and a gyroscope sensor. A gyroscope sensor has an output of angular velocity from the three axes direction namely: $\mathrm{X}$ axis or right and left, $\mathrm{Y}$ axis or top and bottom, and $\mathrm{Z}$ axix or back and front. The 6050 MPU sensor is one of the sensors that uses the basic principle of IMU sensor.

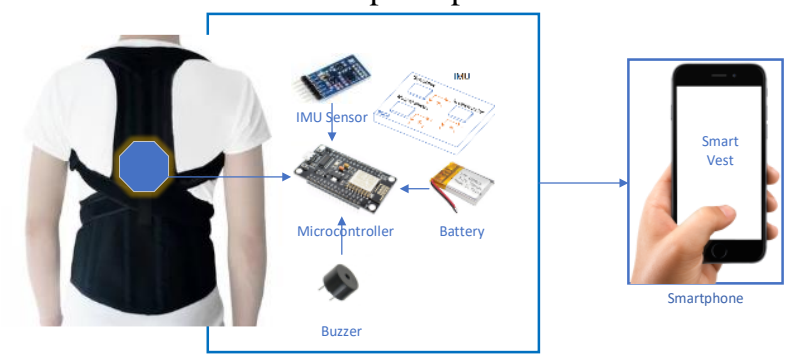

Fig.1. A smart vest prototype

The result of IMU sensor reading will be processed as intelligently as by the Arduino microcontroller. The data of processed result by Arduino will be sent to the smartphone via Bluetooth transmission media then it is sent by Bluetooth module. The display at android application on the smartphone display a information of tilt angle when sitting.

\subsection{Hardware Design}

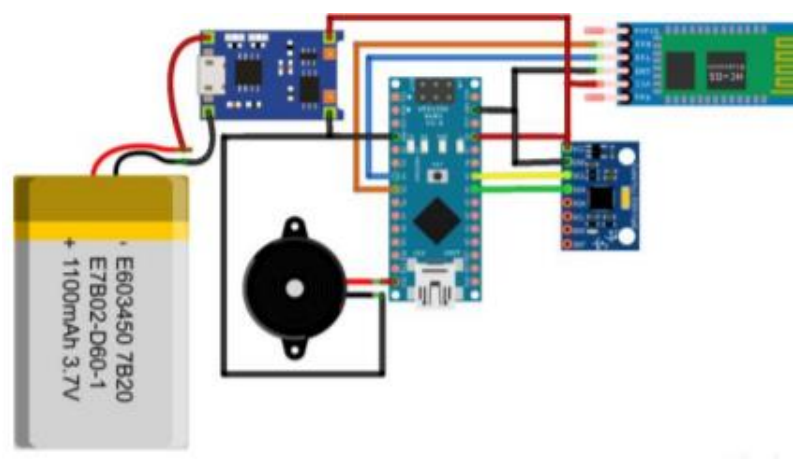

Fig.2. Hardware set design

The set of hardware that will be applied to the smart vest is shown in fig.2. In the series contain IMU sensor that used as input, Arduino microcontroller as process and buzzer as output, there is also a battery as power and Bluetooth module used to send the data.

The hardware design aims to allow a smart vest system can measure the angle change which is detected by the IMU sensor. The angle change that is able to be 
detected by the IMU sensor is the angle of $\mathrm{X}, \mathrm{Y}$ and $\mathrm{Z}$. In this research, the data of angle change only take the $\mathrm{Y}$ angle. It is also use Arduino nano microcontroller, then the RAW data produced by the $6050 \mathrm{MPU}$ sensor will be processed by the microcontroller to be used as an angle.

\subsection{Software Design}

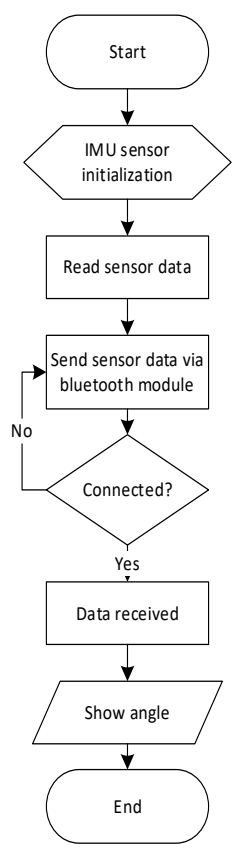

Fig.3. Flowchart of data delivery

In fig. 3 shows a flow from the process of sending sensor data up to displaying the result of sensor reading at an android application on smartphone.

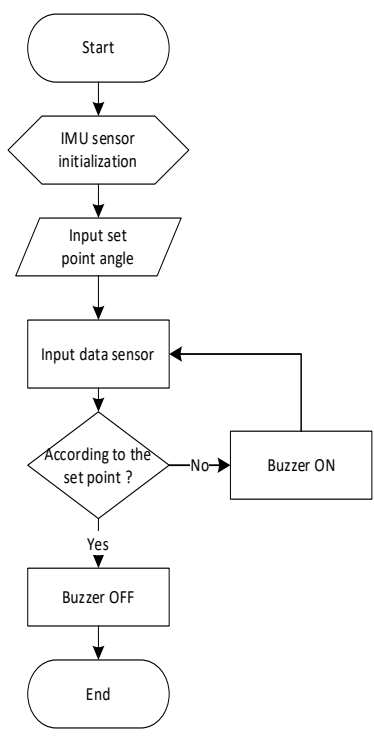

Fig.4. Flowchart program
In fig. 4 we can see the program flowchart diagram in this study, it begins the initialization of the IMU sensor with type MPU 6050. After that it is given a set point angle value as a reference from the reading sensor, the set point angle is used to control when the buzzer is turned on and off.

\section{RESULT}
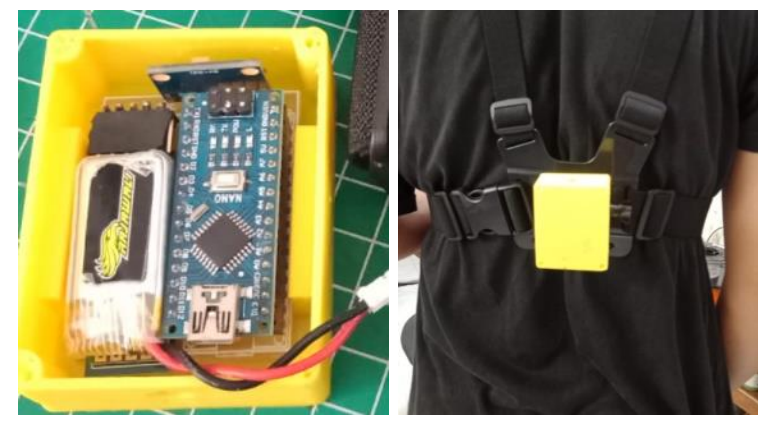

Fig.5. Hardware implementation

Fig.5 shows the result of hardware design's implementation. On the back vest consists a device that is able to warn the user when the user is sitting in the wrong position.

\section{Screen 1 \\ POSISITION CHECKER \\ SCAN \\ Disconnect}

\section{Connected}

Sudut

$:-97.34$

\section{RESET ZERO}

Fig.6 shows the result of implementation's android application on smartphone. In this application, There is a scan menu used to perform a Bluetooth searching of the vest device. Connect menu to connect smartphone device with vest device and angle menu to display the result of angle reading gained from reading sensor.

Table 1. the result of test's Bluetooth connection distance with vest device

\begin{tabular}{ccc}
\hline Test & $\begin{array}{c}\text { Distance } \\
\text { (Meters) }\end{array}$ & Result \\
\hline $\mathbf{1}$ & 5 & Connect \\
\hline $\mathbf{2}$ & 10 & Connect \\
\hline
\end{tabular}




\begin{tabular}{ccc}
\hline $\mathbf{3}$ & 15 & Connect \\
\hline $\mathbf{4}$ & 20 & Connect \\
\hline $\mathbf{5}$ & 25 & Disconnect \\
\hline
\end{tabular}

Based on the result of test's connection distance in Table 1 , the maximum distance range from Bluetooth $\mathrm{HC}-05$ module between the smartphone and the Bluetooth device attached to the vest is 20 meters to 25 is weakened and disconnected signal.

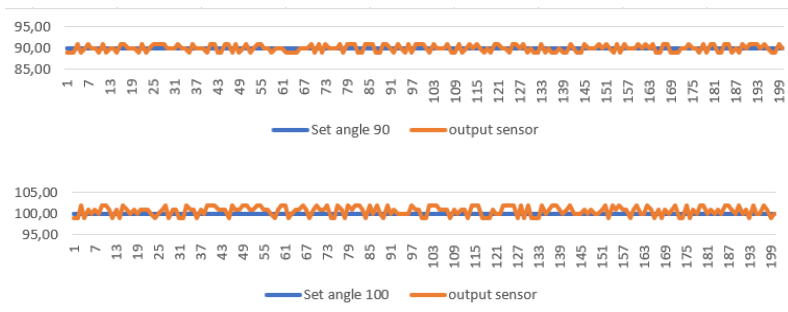

Fig.7. IMU sensor test result with an angle of 90 and 100 degrees.

IMU sensor data that has been used after measurement as shown in the graph in fig.7. The test was conducted by comparing the reading result of IMU sensor with protractor of 200 sample data. Can be seen of result of sensor reading that have a fairly small offsite, it is less than 1 degree from an angle of 90 and 100 degrees.

Table 2. Buzzer test results

\begin{tabular}{ccc}
\hline Test & $\begin{array}{c}\text { Set Angle 90 } \\
\text { 100 Degrees }\end{array}$ & Result \\
\hline $\mathbf{1}$ & 90.40 & Buzzer OFF \\
\hline $\mathbf{2}$ & 90.10 & Buzzer OFF \\
\hline $\mathbf{3}$ & 88.20 & Buzzer ON \\
\hline $\mathbf{4}$ & 85.00 & Buzzer ON \\
\hline $\mathbf{5}$ & 87.10 & Buzzer ON \\
\hline $\mathbf{6}$ & 91.60 & Buzzer OFF \\
\hline $\mathbf{7}$ & 94.10 & Buzzer OFF \\
\hline $\mathbf{8}$ & 97.40 & Buzzer OFF \\
\hline $\mathbf{9}$ & 99.10 & Buzzer OFF \\
\hline $\mathbf{1 0}$ & 101.10 & Buzzer ON \\
\hline
\end{tabular}

Based on the buzzer test results find in Table 2. Buzzer can function properly, it will be in an OFF or standby state when the sitting position is in a tilt condition of 90 to 100 degrees. Buzzer will turn on when the sitting position is tilted under 90 degrees and above 100 degrees.

\section{CONCLUSION}

According to the results of testing vest device, it can draw a conclusion such as the IMU sensor can read the tilt angle with a fairly small offsite that is less than one degree from the actual angle, The buzzer can function as well as possible, the buzzer will turn on if the sitting position is not match the set of point angle that has been determined, for the test of connectivity Bluetooth device can also connect well with a maximum range of 20 meters. Android application can display reading sensor information correctly. For further research on android application can add evaluation feature of sitting position everyday based on the data that has been received from reading sensor.

\section{REFERENCES}

[1] Budiarto, M., Gozali, A. A., \& Hidayaturrohman, H. (2016). Sistem Koreksi Postur Duduk Dengan Betaspc Berbasis Arduino Duemilanove. CCIT Journal, 9(3), 290-302. https://doi.org/10.33050/ccit.v9i3.461

[2] Freitas, K. P. N., Barros, S. S. de, Ângelo, R. di C. de O., \& Uchôa, É. P. B. L. (2011). Lombalgia ocupacional e a postura sentada: efeitos da cinesioterapia laboral. Revista Dor, 12(4), 308$313 . \quad$ https://doi.org/10.1590/s180600132011000400005

[3] Hidayatno, A. (2011). Rancang Bangun Inertial Measurement Unit Sebagai Sistem Monitoring Kendaraan Bergerak Berbasis Sensor Accelerometer Dan Gyroscope. Jurnal Rekayasa Elektrika, 9(4), 166-173.

[4] Liandana, M., Putra, M. A. W., \& Aryanto, K. A. A. (2017). Deteksi Posisi Tubuh pada Aktivitas Pengguna Smartphone Menggunakan Sensor Accelerometer. Konferensi Nasional Sistem \& Informatika, 630-633.

[5] Madona, E., Irmansyah, M., \& Nasution, A. (2018). Sistem Informasi Untuk Posisi Dan Lama Duduk Dengan Smartphone Android Berbasis Mikrokontroler. Elektron: Jurnal Ilmiah, 10(2), 1-5. https://doi.org/10.30630/eji.10.2.75

[6] Putra RS , Legiran, A. M. (2018). Hubungan posisi duduk dan ketidaksesuaian desain tempat duduk sepeda motor dengan kejadian nyeri pingang pada pengendara ojek daring. Majalah Kedokteran Sriwijaya, April, 74-84.

[7] Kurniawan, A. (2019). Arduino Nano A Hands-on Guide For Beginner. PE press.

[8] Kurniawan, A. H., \& Rivai, M. (2018). Sistem Stabiliasi Nampan Menggunakan IMU sensor dan Arduino Nano. JURNAL TEKNIK ITS, A270. 